\title{
Mangromicin C, a new analog of mangromicin
}

\author{
Takuji Nakashima ${ }^{1}$, Yoshiyuki Kamiya ${ }^{2}$, Masato Iwatsuki ${ }^{2,3}$, Noriko Sato ${ }^{4}$, Yōko Takahashi ${ }^{3}$ \\ and Satoshi Ōmura ${ }^{3}$
}

The Journal of Antibiotics (2015) 68, 220-222; doi:10.1038/ja.2014.134; published online 1 October 2014

\begin{abstract}
Mangromicin analogs were discovered in a cultured broth of a rare actinomycete, Lechevalieria aerocolonigenes K10-0216., ${ }^{1,2}$ The mangromicin analogs showed antitrypanosomal and reactive oxygen species (ROS) scavenging bioactivities. Mangromicin analogs have unique structures, including common partial structures, notably a cyclopentadecane skeleton with a tetrahydrofuran unit and a 5,6dihydro-4-hydroxy-2-pyrone moiety. In a previous report, we described eight new mangromicin analogs, which possessed antioxidative properties. At that time, we discovered mangromicin C (1) but were unable to determine its structure, which was clearly different from all the other analogs. We have now found that $\mathbf{1}$ has a structure which includes a tetrahydropyran ring (Figure 1). In this paper, we report the fermentation, isolation, structural elucidation and biological activity of 1.
\end{abstract}

A loop of spores of the strain K10-0216 was inoculated into $100 \mathrm{ml}$ of the seed medium, consisting of $2.4 \%$ starch (Wako Pure Chemical Industries, Osaka, Japan), $0.1 \%$ glucose (Wako), $0.3 \%$ peptone (Kyokuto Pharmaceutical Industrial, Tokyo, Japan), 0.3\% meat extract (Kyokuto), 0.5\% yeast extract (Oriental Yeast, Tokyo, Japan) and $0.4 \% \mathrm{CaCO}_{3}$ (Wako) (adjusted to $\mathrm{pH} 7.0$ before sterilization) in a $500 \mathrm{ml}$ Erlenmeyer flask. The flask was incubated on a rotary shaker (210 r.p.m.) at $27^{\circ} \mathrm{C}$ for 3 days. A $1 \mathrm{ml}$ portion of the seed culture was transferred to $500 \mathrm{ml}$ Erlenmeyer flasks (total 150) containing $100 \mathrm{ml}$ of starch medium, consisting of $2 \%$ soluble starch (Wako), $0.5 \%$ glycerol (Wako), 1.0\% defatted wheat germ (Nisshin Pharma, Tokyo, Japan), $0.3 \%$ meat extract, $0.3 \%$ dry yeast (JT Foods, Tokyo, Japan) and $0.3 \% \mathrm{CaCO}_{3}$ (adjusted to $\mathrm{pH} 7.0$ before sterilization) and fermentation was carried out on a rotary shaker $(210 \mathrm{rpm})$ at $27^{\circ} \mathrm{C}$ for eight days.

The cultured broth of K10-0216 strain (15l) was centrifuged to separate the mycelium and supernatant. The supernatant was extracted three times with ethyl acetate (151). The organic layer was concentrated to dryness in vacuo to afford a crude material $(6 \mathrm{~g})$. The ethyl acetate extract was subjected to silica gel column chromatography FL100D (60 i.d. $\times 200$ mm, Fuji Silysia, Tokyo, Japan), which was sequentially eluted with 11 of a mixture of $\mathrm{CHCl}_{3}-\mathrm{CH}_{3} \mathrm{OH}$ (100:0, 100:1, 50:1 and 10:1) in that order. The eluate fraction (100:1) was concentrated to yield $550 \mathrm{mg}$ and applied to an ODS column (40 i. d. $\times 150 \mathrm{~mm}$; Senshu Scientific, Tokyo, Japan). After washing with $50 \% \mathrm{MeOH}$, the fractions containing 1 were eluted with $60 \% \mathrm{MeOH}$, followed by concentration in vacuo. The eluate fractions $(278 \mathrm{mg})$ were purified by high performance liquid chromatography on an Inertsil ODS-4 column (14 i.d. $\times 250 \mathrm{~mm}$, GL Sciences, Tokyo, Japan)

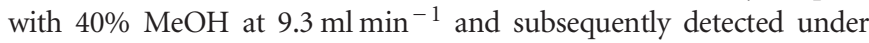
UV light of $254 \mathrm{~nm}$. The yield of 1 was $45.0 \mathrm{mg}$.

Compound 1 was obtained as a white powder $\left([\alpha]_{\mathrm{D}}^{25.3}=+23.2\right.$; $c=0.1$ in $\mathrm{MeOH}) ; \mathrm{UV}(\mathrm{MeOH}) \lambda_{\max }(\varepsilon): 251 \mathrm{~nm}$ (5595), and its infrared spectrum showed the characteristic absorptions of hydroxyl and carbonyl groups $\left(\nu_{\max }, 3430\right.$ and $\left.1657 \mathrm{~cm}^{-1}\right)$. The HR-ESIMS of 1 produced the $[\mathrm{M}+\mathrm{H}]^{+}$ion at $\mathrm{m} / z 395.2413$ indicating the molecular formula was $\mathrm{C}_{22} \mathrm{H}_{34} \mathrm{O}_{6}$ (calculated value for $\mathrm{C}_{22} \mathrm{H}_{35} \mathrm{O}_{6}, 395.2434$ ). Since some broadening signals were observed in $\mathrm{CD}_{3} \mathrm{OD}$, the $1 \mathrm{D}$ and $2 \mathrm{D}$ nuclear magnetic resonance (NMR) spectra of $\mathbf{1}$ were obtained in DMSO- $d_{6}$. The sharpest NMR signals of 1 were observed at $70^{\circ} \mathrm{C}$ among various temperatures (see Supplementary Information).

Mangromicin C (1) structure was elucidated by comparison of the ${ }^{1} \mathrm{H}$ and ${ }^{13} \mathrm{C}$ NMR of other mangromicin analogs. The ${ }^{1} \mathrm{H}$ and ${ }^{13} \mathrm{C}$ NMR spectral data of 1 measured in DMSO- $d_{6}$ at $70^{\circ} \mathrm{C}$ are listed in Table 1 . The ${ }^{1} \mathrm{H}$ NMR data indicated the presence of three oxygenated $s p^{3}$ methines, three $s p^{3}$ methines, containing two methines coupled to methyl groups, seven methylenes, one primary methyl, two secondary methyls and one tertiary methyl. The ${ }^{13} \mathrm{C}$ NMR spectrum showed the resonances of 22 carbons, which were classified into two olefinic carbons, two carbonyl carbons at $\delta_{c} 164.6$ and 209.3, one oxygenated $s p^{3}$ quaternary carbon, three oxygenated $s p^{3}$ methine carbons, three $s p^{3}$ methine carbons, seven $s p^{3}$ methylene carbons and four methyl carbons by heteronuclear-single-quantum coherence spectra.

The ${ }^{1} \mathrm{H}-{ }^{1} \mathrm{H}$ COSY indicated the presence of three partial structures (a) C-8/C-12, C-8/C-8-Me and C-12/C-12-Me, (b) C-15/C-16 (c) $\mathrm{C}-4 / \mathrm{C}-3^{\prime}(\mathrm{Me})$, as shown in Figure 2. Analysis of HMBC data confirmed the presence of a 5,6-dihydro-4-hydroxy-2-pyrone moiety (a partial structure in mangromicins), based on correlations from $\mathrm{H}-4$ to C-2, C-3 and C-6; from $\mathrm{H}-5$ to C-1, C-3 and C-1'; from $\mathrm{H}_{2}-15$ to C-2; and from $\mathrm{H}_{2}-16$ to $\mathrm{C}-1, \mathrm{C}-2$ and C-14. The HMBC correlations

${ }^{1}$ Research Organization for Infection Control Sciences, Kitasato University, Tokyo, Japan; ${ }^{2}$ Graduate School of Infection Control Sciences, Kitasato University, Tokyo, Japan; ${ }^{3}$ Kitasato Institute for Life Sciences, Kitasato University, Tokyo, Japan and ${ }^{4}$ Graduate School of Pharmaceutical Sciences, Kitasato University, Tokyo, Japan Correspondence: Dr T Nakashima, Research Organization for Infection Control Sciences, Kitasato University, Tokyo 108-8641, Japan or Professor Y Takahashi, Kitasato Institute for Life Sciences, Kitasato University, 5-9-1 Shirokane, Minato-ku, Tokyo 108-8641, Japan.

E-mail: takuji@lisci.kitasato-u.ac.jp or ytakaha@lisci.kitasato-u.ac.jp

Received 18 July 2014; revised 22 August 2014; accepted 29 August 2014; published online 1 October 2014 
<smiles>CCC[C@H]1C(O)=C2CC[C@]3(C)C[C@@H](C)[C@@H](O)[C@@H](C[C@@H](C)C(=O)C[C@@H]1O2)OC3=O</smiles>

Figure 1 Relative configurations of mangromicin C (1).

Table $1{ }^{1} \mathrm{H}$ and ${ }^{13} \mathrm{C}$ NMR spectral data for mangromicin $\mathrm{C}$ (1)

\begin{tabular}{|c|c|c|c|}
\hline Position & $\delta_{C}$, mult & $\delta_{H}$ (int., mult., $J$ in $\mathrm{Hz}$ ) & $H M B C$ \\
\hline 1 & 164.6, C & & \\
\hline 2 & 102.1, C & & \\
\hline 3 & $163.4, \mathrm{C}$ & & \\
\hline 4 & $41.5, \mathrm{CH}$ & $2.10(1 \mathrm{H}, \mathrm{dd}, 0.4,4.8)$ & $\mathrm{C}-2, \mathrm{C}-3, \mathrm{C}-6, \mathrm{C}-\mathrm{1}^{\prime}, \mathrm{C}-2^{\prime}$ \\
\hline 5 & $71.3, \mathrm{CH}$ & $4.56(1 \mathrm{H}, \mathrm{dd}, 0.4,9.2)$ & $\mathrm{C}-1, \mathrm{C}-3, \mathrm{C}-6, \mathrm{C}-\mathrm{1}^{\prime}$ \\
\hline $6 a$ & $42.5, \mathrm{CH}_{2}$ & $2.32(1 \mathrm{H}, \mathrm{m})$ & C-4, C-7 \\
\hline $6 b$ & & $4.28(1 \mathrm{H}, \mathrm{dd}, 9.2,15.2)$ & $C-4, C-5, C-7$ \\
\hline 7 & 209.3, C & & \\
\hline 8 & $42.4, \mathrm{CH}$ & $2.63(1 \mathrm{H}, \mathrm{m})$ & C-9 \\
\hline $9 a$ & $36.1, \mathrm{CH}_{2}$ & $1.60(1 \mathrm{H}, \mathrm{m})$ & $\mathrm{C}-7, \mathrm{C}-10, \mathrm{C}-11, \mathrm{C}-8-\mathrm{Me}$ \\
\hline $9 b$ & & $2.28(1 \mathrm{H}, \mathrm{m})$ & C-7, C-10, C-11, C-8-Me \\
\hline 10 & $66.6, \mathrm{CH}$ & $3.41(1 \mathrm{H}, \mathrm{m})$ & C-11 \\
\hline 11 & 80.0. $\mathrm{CH}$ & $3.24(1 \mathrm{H}, \mathrm{dd}, 2.4,5.6)$ & C-9, C-13, C-12-Me \\
\hline 12 & $34.9, \mathrm{CH}$ & $2.27(1 \mathrm{H}, \mathrm{m})$ & C-10, C-11, C-13, C-14 \\
\hline 13 & $47.5, \mathrm{CH}_{2}$ & $1.59(2 \mathrm{H}, \mathrm{m})$ & C-12-Me, C-14-Me \\
\hline 14 & $81.3, \mathrm{C}$ & & \\
\hline $15 a$ & $35.0, \mathrm{CH}_{2}$ & $1.16(1 \mathrm{H}, \mathrm{ddd}, 3.2,3.2,11.2)$ & C-2, \\
\hline $15 b$ & & $2.32(1 \mathrm{H}, \mathrm{m})$ & C-2, C-14 \\
\hline $16 a$ & $18.2, \mathrm{CH}_{2}$ & $1.91(1 \mathrm{H}, \mathrm{ddd}, 3.2,3.2,12.0)$ & C-2, C-14 \\
\hline $16 b$ & & $2.72(1 \mathrm{H}, \mathrm{ddd}, 3.2,3.2,11.2)$ & C-1, C-2 \\
\hline $1^{\prime}$ & 33.1, $\mathrm{CH}_{2}$ & $1.50(2 \mathrm{H}, \mathrm{m})$ & $C-3, C-4, C-5, C-2^{\prime}$ \\
\hline $2^{\prime} \mathrm{a}$ & $19.2, \mathrm{CH}_{2}$ & $1.31(1 \mathrm{H}, \mathrm{m})$ & $\mathrm{C}-1^{\prime}$ \\
\hline $2^{\prime} b$ & & $1.43(1 \mathrm{H}, \mathrm{m})$ & C-4, C-1', C-3' \\
\hline $3^{\prime}(\mathrm{Me})$ & $13.4, \mathrm{CH}_{3}$ & $0.88(3 \mathrm{H}, \mathrm{t}, 8.0)$ & $\mathrm{C}-1^{\prime}, \mathrm{C}-2^{\prime}$ \\
\hline 8-Me & $14.4, \mathrm{CH}_{3}$ & $0.96(3 \mathrm{H}, \mathrm{d}, 6.4)$ & C-7, C-8, C-9 \\
\hline 12-Me & $14.4, \mathrm{CH}_{3}$ & $0.98(3 \mathrm{H}, \mathrm{d}, 5.6)$ & C-11, C-12, C-13 \\
\hline 14-Me & $24.4, \mathrm{CH}_{3}$ & $1.25(3 \mathrm{H}, \mathrm{s})$ & C-13, C-14, C-15 \\
\hline
\end{tabular}

$\ln$ DMSO- $d_{6}\left(70^{\circ} \mathrm{C}\right)$

from $\mathrm{H}-4$ to $\mathrm{C}-2^{\prime}$; from $\mathrm{H}-5$ to $\mathrm{C}-1^{\prime}$; from $\mathrm{H}_{2}-1^{\prime}$ to $\mathrm{C}-3, \mathrm{C}-4, \mathrm{C}-5$, and $\mathrm{C}-2^{\prime}$; from $\mathrm{H}_{2}-2^{\prime}$ to $\mathrm{C}-4, \mathrm{C}-1^{\prime}$ and $\mathrm{C}-3^{\prime}$; and from $\mathrm{H}_{3}-3^{\prime}$ to $\mathrm{C}-1^{\prime}$ and $\mathrm{C}-2^{\prime}$ confirmed an $n$-propyl group linked to the $\mathrm{C}-4$ position. A tetrahydropyran unit was identified, based on $\mathrm{HMBC}$ correlations from $\mathrm{H}_{2}-9$ to $\mathrm{C}-10$ and $\mathrm{C}-11$; from $\mathrm{H}-10$ to $\mathrm{C}-11$ and $\mathrm{C}-14$; from H-11 to C-9 and C-13; from H-12 to C-10, C-11, C-13 and C-14. Moreover, the correlations from $\mathrm{H}-11$ and $\mathrm{H}_{2}-13$ to $\mathrm{C}-12-\mathrm{Me}$; from $\mathrm{H}_{2}-13$ and $\mathrm{H}_{2}-15$ to $\mathrm{C}-14-\mathrm{Me}$; from $\mathrm{H}_{3}-12-\mathrm{Me}$ to $\mathrm{C}-11, \mathrm{C}-12$ and $\mathrm{C}-13$; and from $\mathrm{H}_{3}-14-\mathrm{Me}$ to $\mathrm{C}-13, \mathrm{C}-14$ and $\mathrm{C}-15$ confirmed a secondary methyl and a tertiary methyl linked to the C-12 and C-14 positions, respectively. The $\mathrm{HMBC}$ correlations from $\mathrm{H}_{2}-15$ to $\mathrm{C}-2$ and $\mathrm{C}-14$, and from $\mathrm{H}_{2}-16$ to $\mathrm{C}-1, \mathrm{C}-2$ and C-14 also showed that the

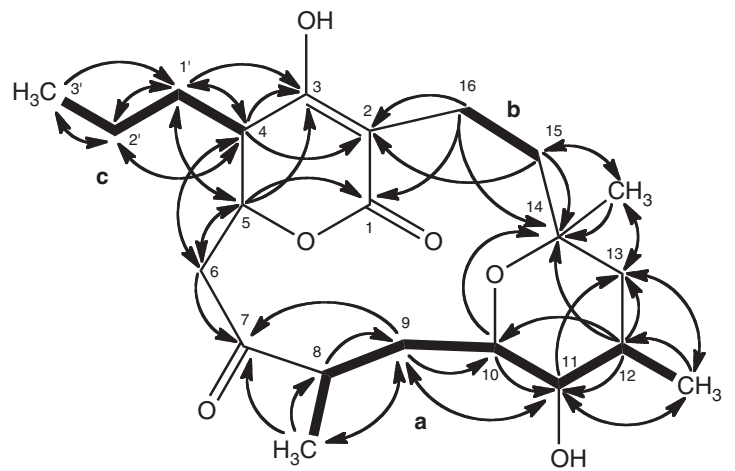

Figure $2{ }^{1} \mathrm{H}-{ }^{1} \mathrm{H}$ COSY (bold) and selected HMBC (arrow) correlations of mangromicin $\mathrm{C}(\mathbf{1})$.

5,6-dihydro-4-hydroxy-2-pyrone moiety and tetrahydropyran ring were connected by an ethylene bond. Finally, the cyclopentadecane ring was confirmed by the $\mathrm{HMBC}$ correlations from $\mathrm{H}_{2}-6$ to C-4, C-5 and C-7; from $\mathrm{H}-8$ to C-9; from $\mathrm{H}_{2}-9$ to C-7, C-10, C-11, and C-8$\mathrm{Me}$; from $\mathrm{H}_{3}-8-\mathrm{Me}$ to $\mathrm{C}-7, \mathrm{C}-8$ and C-9. Therefore, the planar structure of 1 was elucidated as shown in Figure 2, and it was designated as mangromicin C. Compound $\mathbf{1}$ was structurally different from all other mangromicin analogs, which have a tetrahydropyran ring instead of a tetrahydrofuran ring.

The relative configuration of $\mathbf{1}$ was estimated by the ${ }^{1} \mathrm{H}-{ }^{1} \mathrm{H}$ coupling constant analysis, differential NOE and ROESY experiments compared with mangromicin A. ${ }^{1}$ The ROESY correlations, the same as mangromicin A, were observed between $\mathrm{H}-4 / \mathrm{H}-5, \mathrm{H}-4 / \mathrm{H}-6 \mathrm{a}, \mathrm{H}-5 / \mathrm{H}-6 \mathrm{a}$, $\mathrm{H}_{3}-8-\mathrm{Me} / \mathrm{H}-10, \mathrm{H}_{3}-12-\mathrm{Me} / \mathrm{H}_{2}-13, \mathrm{H}_{2}-13 / \mathrm{H}_{2}-15, \mathrm{H}_{2}-13 / \mathrm{H}_{3}-14-\mathrm{Me}$ and $\mathrm{H}_{3}-14-\mathrm{Me} / \mathrm{H}_{2}-16$ (Supplementary Figure $\mathrm{S} 7$ ). In addition, the relative configuration of the tetrahydropyran ring was determined by small coupling constant between $\mathrm{H}-11$ and $\mathrm{H}-10$ or $\mathrm{H}-12$ (Table 1 ), and ROESY correlations between $\mathrm{H}-11 / \mathrm{H}_{3}-12-\mathrm{Me}$ and $\mathrm{H}_{2}-13 / \mathrm{H}_{3}-12-\mathrm{Me}$. Moreover, ROESY correlations of $\mathrm{H}-10 / \mathrm{H}_{3}-8$-Me suggested that $\mathrm{H}_{3}-8$ $\mathrm{Me}$ is $\alpha$-oriented. The coupling constants were observed between $\mathrm{H}-4$ and $\mathrm{H}-5(0.4 \mathrm{~Hz})$ and $\mathrm{H}-5$ and $\mathrm{H}-6 \mathrm{~b}(9.2 \mathrm{~Hz})$. The relative configuration of 1 was proposed as shown in Figure 1.

Compound $\mathbf{1}$ had more potent scavenging activity against 1,1diphenyl-2-picrylhydrazyl free radicals $\left(\mathrm{IC}_{50}=3.8 \mu \mathrm{M}\right)$ than $\alpha$-tocopherol $\left(\mathrm{IC}_{50}=11.4 \mu \mathrm{M}\right)$. In addition, 1 had scavenging activity against nitric oxide generated by lipopolysaccharide-stimulated RAW264.7 cells, a murine-macrophage cell line, at final concentration of $100 \mu \mathrm{M}$, without cytotoxic activity. Compared to the eight other analogs of mangromicin found, mangromicin $\mathrm{C}$ showed moderate anti-oxidant activity against ROS. ${ }^{2}$ ROS are known to be potentially injurious to living organisms because, in excess, they cause oxidative stress and can damage lipids, proteins and nucleic acids. ${ }^{3-5}$ Our results indicate that mangromicin analogs offer potential as ROS scavengers.

\section{ACKNOWLEDGEMENTS}

This study was supported by funds from the Institute for Fermentation (IFO), Osaka, Japan. We thank Kenichiro Nagai, School of Pharmacy, Kitasato University, for measurement of MS spectra, and Takashi Iwashita, Suntory Institute for Bioorganic Research, for advice on NMR spectra.

\footnotetext{
1 Nakashima, T. et al. Mangromicins A and B: structure and anti-trypanosomal activity of two new cyclopentadecane compounds from Lechevalieria aerocolonigenes K10-0216. J. Antibiot. 67, 253-260 (2014) .
} 
2 Nakashima, T., Kamiya, Y., Iwatsuki, M., Takahashi, Y., Omura, S. Mangromicins, six new anti-oxidative agents isolated from a culture broth of the actinomycete, Lechevalieria aerocolonigenes K10-0216. J. Antibiot. 67, 533-539 (2014).

3 Fridovich, I. Biological effects of the superoxide radical. Arch. Biochem. Biophys. 15, $1-11$ (1986)
4 Miller, D.M., Buettner, G.R., Aust, S.D. Transition metals as catalysts of "autoxidation" reactions. Free Radic. Biol. Med. 8, 95-108 (1990)

5 Slater, T.F., Cheeseman, K.H., Davies, M.J., Proudfoot, K., Xin, W. Free radical mechanisms in relation to tissue injury. Proc. Nutr. Soc. 46, 1-12 (1987) .

Supplementary Information accompanies the paper on The Journal of Antibiotics website (http://www.nature.com/ja) 